\title{
Obituary
}

Cells

Tissues

Organs
Cells Tissues Organs 2017;204:326

DOI: $10.1159 / 000479643$

\section{Prof. Dr. med. Dr. h.c. Michael Frotscher (1947-2017)}

Prof. Michael Frotscher, our colleague and associate editor of Cells Tissues Organs, unexpectedly died on May 27, 2017, in Hamburg, Germany, a few weeks before his 70th birthday.

Born in Dresden in 1947, he studied medicine at Humboldt University in Berlin. After leaving the German Democratic Republic in 1979 under precarious conditions, he joined the Max Planck Institute in Frankfurt as a research associate and established his own group there. He set out to study the rodent central nervous system using the state-of-the-art tract tracing methods then available and soon focused on the hippocampus, which became his favorite experimental model. Combining neuronal tracing with immunohistochemistry and a sophisticated Golgi-EM method which he had developed, he and his growing group of pupils and associates disentangled the complex wiring of the hippocampus, mostly using slice cultures.

From 1989 to 2011, he chaired one of the two Anatomy Departments at Freiburg University. After retiring, he moved to Hamburg, where he became director of the Zentrum für Molekulare Neurobiologie and the Institut für Strukturelle Neurobiologie at the Universitätsklinikum Eppendorf.
Over the past decade, he studied synaptic dynamics with real-time microscopy and high-pressure freezing electron microscopy. One of his most significant achievements is the elucidation of the role reelin plays in neuronal migration and establishment of cortical lamination. These important developmental processes were excellently reviewed in his last paper [Frotscher et al., 2017], published a few days before his death.

Prof. Frotscher began working as an associate editor for Cells Tissues Organs in 1996, when it was still called Acta Anatomica. We are very grateful to him for this work and are left with the memory of an eminent and influential scientist, academic teacher, and dedicated anatomist who will be sadly missed.

Winfried L. Neuhuber, Erlangen Hans-Werner Denker, Essen

Reference

Frotscher, M., S. Zhao, S. Wang, X. Chai (2017) Reelin signaling inactivates cofilin to stabilize the cytoskeleton of migrating cortical neurons. Front Cell Neurosci DOI: 10.3389/fncel.2017.00148. 